\title{
FORMAÇÃO: UMA RESPONSABILIDADE SOCIAL
}

\author{
Marina Patrício de Arruda*
}

SINNTESE - O presente artigo busca tecer algumas considerações sobre 0 desenvolvimento de uma dissertação de mestrado que se propõe a estudar como o periódico vem garantindo a construção de concepções e práticas relativas à formação do cidadão e do trabalhador. Essa investigação volta-se para a extensa divulgação de cursos de formação para o trabalho que mostram as ações e estratégias desencadeadas pela sociedade, comprometida com a inserção profissional.

PALAVRAS-CHAVE - periódico, formação, inserção profissional.
ABSTRACT - This present article aims to make some considerations about the development of a dissertation of Masters Degree whose pourpose to study how a periodic has been guaranteeing a construcion of conceptions and pratiques about formation. This investigation relates to the extensive disclosing of work formation courses and shows actions and strategies unleashed by a society commited with professionalinsertion.

KEY WORDS - periodic, formation, professional insertion.

\section{1 - Introdução}

O conjunto de mudanças a que ora assistimos, desencadeado pelo avanço tecnológico, globalização da economia e conseqüente internacionalização do conhecimento, instiga-nos a pesquisar como os periódicos vêm garantindo a construção de concepções e práticas relativas à formação, no decorrer dos últimos anos, tendo em vista as atuais demandas deste fim de século. Importante ressaltar que a formação é um fato eminentemente histórico e suas modificações vão aparecendo na medida em que os modelos adotados se revelam inadequados para satisfazer as necessidades emergentes.

* Licenciada em Ciências Sociais, mestranda em Serviço Social pela PUCRS, bolsista da Coordenação de Aperfeiçoamento de Pessoal de Nivel Superior - CAPES.

1 O jomal Zero Hora é o principal veiculo da midia impressa da Rede Brasil Sul (RBS). É um jornal em formato de tablóide com circulação diária, sendo domingo o seu dia de maior circulação. Segundo pesquisa realizada junto a leitores diários de jornais no Rio Grande do Sul, num total de 1.014 .600 (48\% da população), 709.000 (34\%) são leitores de Zero Hora e 448.800 (21\%) são leitores do Correio do Povo (Fonte: Ibope, dez. 1997 a fev. 1998). 
Pretendemos então discutir neste artigo resultados parciais de um projeto em desenvolvimento que tem por objetivo maior analisar as principais orientações emitidas pelo periódico Zero Hora, ${ }^{1}$ sobre as práticas e concepções relativas à formação.

É evidente que o processo de formação sofreu mudanças ao longo dos anos, em decorrência das constantes exigências de mercado. Até a mietade deste século, a formação apresentava um cunho totalizante, rígido e autoritário, porém, atualmente, tal processo se firma em moldes mais globalizantes ${ }^{2}$ porque a tecnologia impõe um ritmo acelerado de muđanças sociais e econômicas, implicando uma constante reposição de saberes que supõem relações sociais mais democráticas.

Nessa perspectiva, a categoria formação em contexto de globalização passa a envolver várias outras dimensões referentes à vida social, como aprendizagem, reciclagem, aperfeiçoamento, formação profissional, significando um processo de formação contínua, ou, como vêm registrando os periódicos, a exigência de um perfil mínimo que permita acompanhar as mudanças tecnológicas.

Vale ressaltar, porém, que de fato, nem a literatura sociológica nem o debate social registrado pela imprensa deixam claro o uso do conceito de formação ${ }^{3}$. Sabe-se, contudo, que ela envolve conhecimentos abstratos e técnicos, saberes adquiridos dentro e fora dos sistemas educativos. A formação não é mais patrimônio exclusivo desses sistemas, sua aquisição se dá através de um processo contínuo e múltiplo, o que permite incluir dentro desse conceito as experiências e a socialização adquiridas em outras esferas sociais.

As considerações expostas até aqui deixam clara a impossibilidade de se discutir formação de forma deslocada do contexto atual de mudanças. Isso porque os novos postos de trabalho estão a requerer profissionais mais flexiveis, tendo em vista as pressões por inovações contínuas para atender às exigências produtivas. É nessa perspectiva que a pesquisa em questão se propõe a analisar o tipo de formação necessária ao profissional do século XXI, considerando esse fenômeno enquanto produto das relações estabelecidas entre os diversos campos que compõem o espaço social.

\section{2 - Investigando o periódico}

Essa pesquisa vem-se desenvolvendo através de um sistema de hipóteses, desencadeado a partir da reorganização do mercado de trabalho atual que, tendo em vista o avanço tecnológico e a globalização da economia, passa a demandar um novo perfil de profissional. Nesse contexto, vamos encontrar o periódico enfatizando a necessidade de formação contínua para um mundo que muda tão depressa, formação esta que supera a acadêmica, não envolvendo apenas conhecimentos técnicos, mas também a articulação entre escolaridade e experiência. E, como investir em capital humano é vital para a economia moderna, o periódico, frente à

2 Estas informações podem ser encontradas em: DESAULNIERS, Julieta B. R. Trabalho: a escola do trabalhador? Tese de doutorado defendida junto ao Programa de Pós-Graduação em Educação da Universidade Federal do Rio Grande do Sul, em março de 1993.

3 LOPE y ARTLES. "Las relaciones entre formación y empleo: Que formación, para que empleo?" In: Formação \& trabalho \& competência. Porto Alegre: EDIPUCRS, 1998 p. 186. 
demanda tão emergente, também não se furta a veicular informações sobre o surgimento de uma gestão socializada que inclui ações do Estado, empresários e redes sociais comprometidos com a facilitação das condições para a inserção profissional.

Ao final desse sistema de idéias, encontramos o periódico enquanto agente formador de opinião, produzindo, num movimento constante e infinito, conceitos e práticas relativas à formação. Por isso, essa pesquisa considera a necessidade de investigar o fenômeno da formação sob um prisma definido e construído em diferentes espaços sociais em que intervêm atores sociais também diversos, cuja lógica de atuação se dá de maneira conflitiva e interativa, tendo em vista o sistema produtivo capitalista.

A metodologia que está sendo adotada nesta pesquisa baseia-se na técnica de análise de conteúdo de vários artigos coletados junto à Zero Hora, a partir dos três últimos anos.

\section{3 - A responsabilidade civil}

O periódico em questão apresenta-nos discussões "que enfocam a formação enquanto uma questão de responsabilidade civil", ${ }^{4}$ da mesma forma que a presente pesquisa, em andamento, já nos permite anunciar que a necessidade de formação contínua é um tema recorrente na Zero Hora. Nessa perspectiva, encontramos uma divulgação extensiva de cursos de formação para o mercado de trabalho e de programas de reciclagem profissional, associados ao empenho da sociedade em investir em formação, seja através das práticas do Estado (reformas do ensino, nova Lei de Diretrizes e Bases da Educação, reestruturação de cursos técnicos), seja pelos empresários (projetos de qualificação de recursos humanos, organização do primeiro canal educativo de tevê).

Enfim, várias são as frentes ou movimentos desencadeados contra o analfabetismo, financiadas por oNGs, empresas privadas ou órgãos públicos. Assim, a maneira como este assunto vem sendo tratado pelos periódicos em geral e, em particular pela Zero Hora, indica claramente a importância que a concepção e práticas de formação contínua vêm assumindo junto à nova organização do trabalho. Em outros termos, o assunto é tratado como um fato na ordem do dia pela maioria dos veículos de comunicação de massa.

Sem dúvida, verifica-se, através do periódico Zero Hora, a reorganização de diversos setores da sociedade ao desenvolver estratégias voltadas às práticas de formação que visam a inserção profissional num mercado cada vez mais competitivo. Ao nos aprofundarmos na investigação sobre as relações entre formação e emprego, pretendemos contribuir com novos elementos para o desenvolvimento do contexto atual, tendo em vista as dificuldades cada vez mais crescentes de inserção profissional. É nesse sentido que a sociedade, em tempos de globalização da economia e avanço tecnológico, é convocada pelo periódico a participar.

4 "Filósofo americano fala de globalização". Zero Hora, 26 abr. 1998, p. 73. 
"É papel do Estado lutar pela eliminação de qualquer empecilho que se interponha entre a criança e a sala de aula. [...] A sociedade, porém, tem importante cota de colaboração a dar, e é o que se espera dela nesse momento." 5

Estas orientações também se repetem em outros textos, como este a seguir:

"Embora seja tarefa do Estado, a educação é responsabilidade coletiva [...]. A parceria com o poder público é também o reconhecimento por parte das empresas do papel social que precisam desempenhar...É necessário que, junto com o poder público, as empresas e a sociedade assumam os pesados custos do atraso, da ignorância e da desigualdade." 6

\section{4 - Conclusão}

Indiscutivelmente, para se apreender o movimento deste processo de construção social de conceitos e práticas relativas à formação através de periódicos, fazse necessária a análise das articulações estabelecidas por meio das relações de disputa pelo poder nos vários campos que constituem o espaço social e, em especial, no campo cultural. ${ }^{7}$ É nesta medida que vamos descobrindo a formação enquanto uma responsabilidade social. Ou seja, a sociedade civil vem sendo convocada a assumir, cada vez mais, uma proposta pedagógica voltada à formação do cidadão.

Com essas reflexões objetivamos contribuir para um melhor entendimento sobre as orientações emitidas pelo periódico Zero Hora, quanto às práticas relativas à formação, evidenciando sua implicação referente à responsabilidade social.

"Matricula para todos". Zero Hora, 9 fev. 1998, p. 16.

"O canal do conhecimento". Zero Hora, 22 set. 19/97, p. 20.

Esta pesquisa utiliza alguns referenciais, entre eles a análise proposta por Pierre Bourdieu. 